conduct of business is expressed by this motto with which one William Benedict prefaced his book on the subject in 1698 :

$$
\begin{aligned}
& \text { "Wer sich in Müntz und Wechseln ubt, } \\
& \text { Vergleichung der Gewichte liebt } \\
& \text { Und Maass und Elle richtig giebt"; }
\end{aligned}
$$

which may be freely rendered:

$$
\begin{aligned}
& \text { "Who by finance and commerce liveth } \\
& \text { All measurements correctly giveth; } \\
& \text { And loveth ever such a one } \\
& \text { Of weights the just comparison." }
\end{aligned}
$$

\title{
Jin Altemoriam
}

IN THE last month the Society has lost from its membership Mr. Felix Fuld, who has long been a prominent figure in the world of business, and in those of art and philanthropy as well. He died on January 20, at his home in South Orange, New Jersey. Mr. Fuld was born in Frankfurt-on-Main, Germany, in I 869, and came to America when he was fourteen. His father, Ludwig Fuld, was a partner in a New York banking firm. The boy was privately educated in New York.

Three months after the founding of the Newark department store of L. Bamberger and Company, in 1892 , the younger Fuld joined Louis Bamberger as an equal partner. At the time of his death Mr. Fuld was vice president, treasurer and general manager. He was also vice-president of the WOR radio station owned by the store, and was connected with various publishing and banking activities.

In philanthropic circles he was no less active than in business, although he was extremely reticent about his good works. He was head of the Newark Federation of Jewish Charities, and of the State Federation of Young Men's and Young Women's Hebrew Associations, and a member of the board of directors of the Beth Israel Hospital in Newark. When the Newark Community Chest campaign fell $\$ 150,000$ short of its goal recently, Mr. Fuld and one other man made good the deficit. There was no end to his interest in any worthy cause. He did much in the way of providing social centers for young men and women. Both he and his wife, formerly Miss Carrie Bamberger, contributed largely in aid of Jewish farm 
settlement in Russia. He was interested as well in encouraging the arts, and was a supporter of the New York Philharmonic Society and kindred institutions. It is difficult to reckon the full extent of his contribution to the public welfare, for so much of it was made anonymously, and the value of his boundless enthusiasm and energy added infinitely to what can be done with financial aid, no matter how generously given. Mr. Fuld lent his coöperation to the work of The Business Historical Society, and this organization will feel his loss keenly, as will every cause with which his name was identified.

\section{Secretary's Column}

Among the many acquisitions received since the last issue of the Bulletin the following have been selected as being of especial interest:

From James S. Robinson, Brookline, a scrap book of early day advertisements.

From F. C. Thompson, Manager, National Life Insurance Company, Chattanooga, Tennessee, two boxes of state insurance reports.

From Joseph P. Day, New York, Sir Thomas Culpeper, "A discourse shewing the many advantages which will accrue to this Kingdom by the abatement of Usury," I668. Also - The South Sea Company The Nation preserved - 1720.

From William E. Pulliam, General Receiver, Dominican Customs, Santo Domingo, Dominican Republic, Reports of the Dominican Customs Receivership for 1924 to 1927 , inc., and the Tariff Law on imports and exports, 1920 .

From George C. Warren, Warren Brothers and Company, Boston, Collection of material relating to the discovery and history of asphaltum.

From an officer of the Society, Original parchments dated from 1757 to 1770, covering one marriage settlement, one deed to certain manors and estates, three leases of certain properties in England and a certificate of appointment as Commissioner for taking affidavits executed in the reign of King George the Third.

From William F. Burdett, Assistant Cashier, Merchants National Bank, Boston, A historical sketch of the State Bank, I8II to I865, and the State National Bank, I865 to I8gi, by Amos W. Stetson.

From Charles H. Tuttle, Rutland, Vermont, Plan of Association of North American Land Company, which involved Robert Morris and his associates, $\mathbf{1 7 9 5}$. 